\title{
Potential of human $\gamma$ D-crystallin for hair damage repair: insights into the mechanical properties and biocompatibility
}

\author{
A. Ribeiro* ${ }^{\dagger \dagger}$, T. Matamá ${ }^{\dagger \dagger}$, C. F. Cruz ${ }^{* \dagger}$, A. C. Gomes ${ }^{\dagger}$ and A. M. Cavaco-Paulo* \\ *IBB-Institute for Biotechnology and Bioengineering, Centre of Biological Engineering, Universidade do Minho, Campus de Gualtar, 4710-057, Braga, \\ and 'Department of Biology, Centre of Molecular and Environmental Biology (CBMA), Universidade do Minho, Campus de Gualtar, 4710-057, Braga, \\ Portugal
}

Received 25 January 2013, Accepted 02 May 2013

Keywords: Greek key motif, hair treatment, human crystallin, mechanical properties improvement, over bleached hair

\begin{abstract}
Synopsis
OBJECTIVES: The objective of this work was to develop a new strategy to physically 'repair' chemically damaged hair. Hence the human eye $\gamma \mathrm{D}$-crystallin, a protein from the superfamily characterized structurally by the Greek key motif, was studied. The human $\gamma \mathrm{D}$-crystallin was chosen based on the ability of proteins belonging to this superfamily to be involved in the coating of specific structures. Two crystallins were used on the study, the wild type (Protein Data Bank ID: 1HKO) and the mutant protein. The mutant form was intended to induce a strong and quick protein polymerization as well to have new possible points of anchorage to hair.

METHODS: The ability of both crystallins to bind to damaged hair and even penetrate into its cortex was checked by fluorescence microscopy, confocal microscopy and scanning electron microscopy. Furthermore the reinforcement of hair mechanical resistance, the potential cytotoxic/inflammatory effect of crystallins were studied in order to have a fully comprehension about the protein based formulation.

RESULTS: Although the chemical over-bleaching treatment induced a decrease of $20 \%$ on the resistance of the hair, the crystallins which bind and penetrate the hair fibre were able to recover and even to improve its mechanical properties when compared to the virgin hair. Moreover none of the crystallins displayed a toxic effect in fibroblasts for all the range of tested concentrations upon $72 \mathrm{~h}$ of exposure. The active aggregation process of mutant crystallin induced an inflammatory response in fibroblasts in the first $24 \mathrm{~h}$ of contact, measured by the amount of released pro-inflammatory cytokine IL-6 to the medium. In contrast contact with wild type crystallin did not lead to significant inflammation.

CONCLUSION: Outcome from protein formulation characterization supports the hypothesis that the $\gamma \mathrm{D}$-crystallin it is able to recover and improve the mechanical properties of chemical damaged hair. Therefore it can be considered as a very promising strengthening agent for the development of new restorative hair care products.
\end{abstract}

\section{Résumé}

OBJECTIFS: L'objectif de ce travail était de développer une nouvelle stratégie pour physiquement "réparer" les cheveux chimique-

Correspondence: Artur Cavaco-Paulo, Department of Biological Engineering, Campus de Gualtar, University of Minho 4710-057 Braga, Portugal. Tel.: (+351) 253604310; fax. (+351) 253678980; e-mail: artur@deb.uminho.pt ment endommagés. La protéine humaine $\gamma \mathrm{D}$-cristalline, une protéine de la superfamille caractérisée structurellement par le motif clé grecque, a été étudiée. Le $\gamma \mathrm{D}$-cristallin humain a été choisi en fonction de la capacité des protéines appartenant à cette superfamille d'être impliquées dans le revêtement des structures spécifiques. Deux cristallins ont été utilisés dans l'étude, le type sauvage (Protein Data Bank ID: 1HK0) et la protéine mutante. La forme mutante était destinée à induire une polymérisation de la protéine, forte et rapide ainsi d'avoir de nouveaux points d'ancrage possibles aux cheveux.

MÉTHODES: La capacité des deux cristallins de se lier aux cheveux abîmés et même de pénétrer dans le cortex a été vérifiée par microscopie à fluorescence, microscopie confocale et la microscopie électronique à balayage. En outre, le renforcement de la tenue mécanique des cheveux, l'effet cytotoxique/inflammatoire potentiel de cristallins ont été étudiés en vue d'avoir une compréhension complète de la formulation à base de ces protéines.

RÉSULTATS: Bien que le traitement chimique de sur-blanchiment induise une diminution de $20 \%$ de la résistance des cheveux, les cristallins qui se lient et pénètrent la fibre capillaire ont pu récupérer et même d'améliorer ses propriétés mécaniques par rapport aux cheveux non-traités. Par ailleurs aucun des cristallins n'affiche d'effet toxique dans les fibroblastes pour toute la gamme des concentrations testées sur les 72 heures suivant l'exposition.

Le processus d'agrégation active du cristallin mutant induit une réponse inflammatoire dans les fibroblastes dans les premières 24 heures de contact, mesurée par la quantité de sécrétion de cytokine proinflammatoire IL-6 dans le milieu. Par contre, le contact avec le type sauvage de cristallin n'a pas conduit à une inflammation notable.

CONCLUSION: Le résultat des études de la caractérisation et de la formulation de protéines soutient l'hypothèse que le $\gamma \mathrm{D}$-cristallin est capable de récupérer et d'améliorer les propriétés mécaniques des cheveux abîmés chimiquement. Par conséquent, il peut être considéré comme un agent de renforcement très prometteur pour le développement de nouveaux produits de soins capillaires réparateurs.

\section{Introduction}

Hair plays a key role in our appearance and reflects our physical state. Therefore, there is great interest in the development of new hair care products that facilitate repair and prevent adverse effects on the capillary structure. Cosmetics to adorn or to change the appearance of scalp hair are widely used in any society. 
One of the most popular hair treatments is bleaching. Bleaching lightens the natural hair tone, but it is still more often used to prepare the hair for dyeing [1]. It involves partial or complete decolouring of the existing natural melanin content of the hair. The oxidation reaction associated with bleaching not only alters melanin but also destroys disulphide bonds within the keratin, which will weaken the hair fibre. Damage also occurs at the cuticle level and will make the hair more porous. Following bleaching, hair will often display a different texture, will break more easily and may be more susceptible to humidity [2].

To overcome these problems, a conditioner is often used either in the bleaching solution or after bleaching [3]. Apart from other functions, conditioners protect the hair fibre from further damage by forming a thin coating over the hair fibres.

We aimed to develop a new product for protection and repair of damaged hair by taking advantage of human $\gamma$-crystallin properties.

The beneficial effects of using protein-rich substances in formulations of various topical applications are recognized by many authors [4]. Proteins are considered useful ingredients for creating a suitable environment for healthy skin and hair because of their ability to bind water with the horny layer of skin and its annexes. Moreover, their binding properties to skin and hair suggest a potential role as hair-conditioning agents [5].

Crystallins are the major proteinaceous components in the cytoplasm of fibre cells in the lens, a tissue where the biochemical, thermodynamic and optical properties of its constituent proteins closely intertwine [6]. A common structural feature within the $\beta \gamma$ crystallin family is a pair of domains containing two tightly packed Greek key $\beta$-sheet motifs $[7,8]$. This fold, with additional contributions from domain interactions, contributes towards an unusually high thermodynamic stability [9].

The Greek key motif was recognized as a supersecondary structure by Richardson in 1977. It is composed of four anti-parallel $\beta$ strands with $+3,-1$ and -1 connectivities. In two-dimensional graphical representations, the motif resembles and is named after the repeating unit of a decorative pattern frequently found on Greek pottery [10]. A distinguishing feature of the Greek key is that the first and fourth $\beta$-strands are at opposite ends of the primary structure, but are adjacent in the motif. All Greek key domains invariably comprise a pair of Greek keys [11].

Human $\gamma$ D-crystallin was chosen for the development of protective thin hair coatings based on the ability of proteins structurally characterized by the Greek key motif to be involved in the coating of specific structures, such as the spore coat protein S from Myxococcus xanthus [12].

The aim of this study was to evaluate the potential of $\gamma \mathrm{D}$-crystallin protein as a new strengthening agent for damaged hair. The ability of $\gamma \mathrm{D}$-crystallin to form thin-layer coatings was exploited as a protective agent of the integrity of hair as well as a booster of their mechanical properties directly related to the fibre strength.

A full characterization of the protein-based formulation was pursued through the evaluation of the reinforcement of hair mechanical resistance, their ability to form a thin coating over the hair fibre and the study of potential cytotoxic/inflammatory effect of crystallins.

\section{Materials and methods}

\section{Materials}

Natural Asian black human hair samples were provided by International Hair Importers \& Products Inc. (Glendale, New York,
U.S.A.). Crystallins, wild type (wt) and mutant (mut), based on the sequence of human eye crystallin, were synthesized by GenScript USA Inc. (Piscataway, NJ, U.S.A.). Sequences of both proteins are presented in Table I. All other reagents used were of analytical grade and purchased from Sigma-Aldrich, Madrid, Spain.

\section{Methods}

\section{Hair treatments}

Black Asian Hair fibre samples $(0.1 \mathrm{~g})$ were washed before treatment with a classic commercial shampoo (Pantene). The hair samples were then subjected to eight cycles of bleaching $(8 \mathrm{xB})$. Bleaching consisted of the application of $12 \% \mathrm{H}_{2} \mathrm{O}_{2}(\mathrm{v} / \mathrm{v})$ in the presence of $0.1 \mathrm{~mol} \mathrm{~L}{ }^{-1} \mathrm{Na}_{2} \mathrm{CO}_{3} / \mathrm{NaHCO}_{3}$, pH 9.0 buffer at $50^{\circ} \mathrm{C}$ for $1 \mathrm{~h}$, in a bath ratio of $1: 10$. Treatments were applied to the same tresses of hair. Hair samples were then subjected to the treatment with crystallins. Treatments were performed for $1 \mathrm{~h}$ at $37^{\circ} \mathrm{C}$ with $0.2 \mathrm{mg} \mathrm{mL}^{-1}$ of wt and mut crystallins in $50 \mathrm{mmol} \mathrm{L}^{-1}$ Tris$\mathrm{HCl}, 150 \mathrm{mmol} \mathrm{L}^{-1} \mathrm{NaCl}, 5 \%$ glycerol $(\mathrm{v} / \mathrm{v}), \mathrm{pH} 8.0$ (protein buffer). Samples incubated in the same buffer of $0.2 \mathrm{mg} \mathrm{mL}^{-1}$ bovine serum albumin (BSA) labelled with FITC were treated as a control. Subsequently, all samples were thoroughly washed in tap water with a commercial shampoo.

\section{FITC linkage to crystallins}

To enable the study of crystallin incorporation/adhesion onto overbleached hair as well as the formation of a film on the surface of the hair shafts, fluorescein 5(6)-isothiocyanate (FITC) was linked to the test proteins. A volume of $2 \mathrm{~mL}$ of $1.5 \mathrm{mg} \mathrm{mL}^{-1}$ of crystallin protein (wt and mut) in $50 \mathrm{mmol} \mathrm{L}^{-1}$ Tris- $\mathrm{HCl}, 150 \mathrm{mmol} \mathrm{L}^{-1}$ $\mathrm{NaCl}, 5 \%$ glycerol, pH 8.0 buffer was incubated with $100 \mu \mathrm{L}$ of a $1 \mathrm{~g} \mathrm{~L}^{-1}$ FITC solution at $4^{\circ} \mathrm{C}$. Unbound FITC was separated from the conjugate by passing the mixture through a desalting column PD10. The ratio of fluorescence to protein (Molar $F / P=0.51$ ) was calculated in order to determine labelling efficiency. The estimated value was within the ideal limits (0.3-1.0), indicating efficient labelling.

Labelled crystallins were used in the treatment of overbleached black Asian hair as described earlier.

Table I Wild-type crystallin and mutant crystallin sequences. Characters in bold correspond to the replacement of arginine residues by cysteines in the mutant form

\begin{tabular}{lll}
\hline & Sequence & Mw (Da) \\
\hline \multirow{3}{*}{ Crystallin wt } & MHHHHHHMGKITLYEDRGFQGRHYESS & 21692.0 \\
& DHPNLQPYLSRCNSARVDSGWMLYEQPN & \\
& YSGLQYFLRRGDYADHQQWMGLSDSVRS & \\
& CRLIPHSGSHRIRLYEREDYRGQMIEFTEDC & \\
& SCLQDRFRFNEIHSLNVLEGSWVYELSNY & \\
& RGRQYLLMPGDYRRYQWWATNARVGS & \\
& RRVIDFS & \\
Crystallin mut & MHHHHHMGKITLYEDRGFQGCHYECSS & 21533.0 \\
& DHPNLQPYLSRCNSACVDSGCWMLYEQPN & \\
& YSGLQYFLRRGDYADHQQWMGLSDSVRS & \\
& CCLIPHSGSHRIRLYEREDYRGQMIEFTEDC & \\
& SCLQDRFRFNEIHSLNVLEGSWVYELSNY & \\
& RGRQYLLMPGDYRRYQDWGATNARVGSL & \\
& RRVIDFS \\
\hline
\end{tabular}




\section{Fluorescence microscopy}

Transversal cuts of hair fibre samples were analysed by fluorescence microscopy. Fibre transversal cuts $(15 \mu \mathrm{m})$ of hair fibres embedded in an epoxy resin were prepared using a microtome (Microtome Leitz, Oberkochen, Germany). Cross-sections were analysed using LEICA DM 500B fluorescence microscope (Leica, Berlin, Germany). All images were recorded using similar filter, exposure, brightness and gain settings.

\section{Confocal microscopy}

Samples of hair fibres were imaged using a laser scanning confocal microscope (Olympus FluoView 1000 equipped with a UPlansApo 606objective in 1.4 oil immersion objective, Tokyo, Japan). Hair fibres treated with fluorophore-labelled crystallins were excited using a 488-nm argon laser (515- to 540-nm emission collected). 3D reconstructions were made using the IMARIS 7.6 - BITPLANE software (Zurich, Switzerland).

\section{Scanning electron microscopy}

Hair fibres were taken randomly from the hair tress and mounted onto aluminium stubs using conductive carbon adhesive tape. Hair samples were coated with $80 \% \mathrm{Au}$ and $20 \%$ Pd before SEM (NOVA NanoSEM 200 FEI, Eindhoven, the Netherlands) observation at $5.0 \mathrm{kV}$.

\section{Mechanical properties}

The effect of crystallins on overbleached hair was assessed by the differences in mechanical properties following guidelines outlined in ASTM D1145-95 for fibre tensile testing. For this test, a set of hair fibres with low variability in diameter was selected using a light microscope. The measurements were performed using an Instron 4505 tensile tester with a load cell capacity of $2.5 \mathrm{~N}$. For each measurement, 30 single hair fibres were randomly taken from the tress. Each hair was individually mounted in the tensile jig by means of a paper template with a fixed gauge length of $20 \mathrm{~mm}$. Before the tensile test, the paper template was cut across. Measurements were performed under controlled conditions $\left(20 \pm 0.8^{\circ} \mathrm{C} ; 62 \pm 6 \%\right.$ humidity) at a rate of $1.5 \mathrm{~mm} \mathrm{~min}^{-1}$ until breakage. For each hair, records of applied load against extension were taken and, using an average mean diameter of $70 \mu \mathrm{m}$, data were converted to stress (load/unit area) against strain (\% extension). All measurements were made in the middle part of the hair fibre.

\section{Cytotoxicity evaluation}

Culture of human skin fibroblast cell line (BJ-5ta)

BJ-5ta cell line was used as model of general cytotoxicity. The BJ5ta cell line (normal human skin fibroblasts immortalized by overexpression of telomerase) was maintained according to ATCC recommendations (four parts of Dulbecco's modified Eagle's medium (DMEM) containing $4 \mathrm{mmol} \mathrm{L}^{-1}$ L-glutamine, $4.5 \mathrm{~g} \mathrm{~L}^{-1}$ glucose, $1.5 \mathrm{~g} \mathrm{~L}^{-1}$ sodium bicarbonate and 1 part of Medium 199, supplemented with $10 \%(\mathrm{v} / \mathrm{v})$ of foetal bovine serum (FBS), $1 \%(\mathrm{v} / \mathrm{v})$ of penicillin/streptomycin solution and $10 \mu \mathrm{g} \mathrm{ml}^{-1}$ hygromycin B). The cells were maintained at $37^{\circ} \mathrm{C}$ in a humidified atmosphere with $5 \% \mathrm{CO}_{2}$. Culture medium was replaced every 2 days.
MTT assay

The MTT (3-(4,5-dimethylthiazol-2-yl)-2,5-diphenyltetrazolium bromide) assay is widely used to measure the toxicity of different substances in cell cultures. MTT enters the cells by endocytosis and is reduced to formazan by NADH reductase and other enzymes, which can be measured spectrophotometrically. The amount of formazan reflects the reductive potential of the cytoplasm and the cell viability [13].

Cells were seeded at a previously optimized density of 80000 cells per well on a 24-well tissue culture polystyrene (TCPS) plates (TPP, Trasadingen, Switzerland) the day before experiments. They were then exposed to three concentrations of each crystallin $-0.1,0.2$ and $0.4 \mathrm{mg} \mathrm{mL}^{-1}-$ and three concentrations (v/v) of $50 \mathrm{mmol} \mathrm{L}^{-1}$. Tris-HCl, $150 \mathrm{mmol} \mathrm{L}{ }^{-1} \mathrm{NaCl}, 5 \%$ glycerol, pH 8.0 buffer $-6.6 \%, 13.2 \%$ and $26.4 \%$. Cells were incubated at $37^{\circ} \mathrm{C}$ in a humidified atmosphere with $5 \% \mathrm{CO}_{2}$. At the end of 24 , 48 and $72 \mathrm{~h}$ of contact, cell metabolic activity was assessed using MTT viability assay.

Aqueous MTT solution was added to each well $(50 \mu \mathrm{L})$, and the mixture was incubated at $37^{\circ} \mathrm{C}$ for $2 \mathrm{~h}$. The MTT solution was carefully decanted, and formazan was extracted from the cells with $500 \mu \mathrm{L}$ of a DMSO-EtOH $[1: 1(\mathrm{v} / \mathrm{v})]$ mixture in each well. Colour was measured with a 96-well ELISA plate reader at $550 \mathrm{~nm}$, with the reference filter set to $620 \mathrm{~nm}$ in a microplate reader (Spectramax 340PC, Molecular Devices, Sunnyvale, CA, U.S.A.). All MTT assays were repeated independently three times.

Evaluation of the inflammatory effect of crystallins - ELISA

The evaluation of potential pro-inflammatory activity of both wt and mut crystallins was performed using BJ-5ta cell line as in vitro cellular model. Cells were seeded at a density of 430000 cells per well on a six-well TCPS plate (TPP) 2 days before experiments and then exposed to $0.2 \mathrm{mg} \mathrm{mL}^{-1}$ of each crystallin in $50 \mathrm{mmol} \mathrm{L}^{-1}$ Tris- $\mathrm{HCl} \mathrm{pH} 8$ buffer with $150 \mathrm{mmol} \mathrm{L}^{-1} \mathrm{NaCl}$ and $5 \%$ glycerol. After 24 and $48 \mathrm{~h}$ of incubation, cell culture supernatants were collected and quantitative determination of the pro-inflammatory cytokine IL-6 was performed by sandwich ELISA according to the manufacturer's instructions (MabTech, Stockholm, Sweden). All assays were carried out in duplicate.

\section{Statistical analysis}

Data are presented as average standard deviation (SD), $n=3$. Statistical comparisons were performed by one-way ANOVA with GraphPad Prism 4.0 software (La Jolla, CA, U.S.A.). Tukey's posthoc test was used to compare all the results between them, and a Dunnet's test was used to compare the results with a specific control. A $P$-value of $<0.05$ was considered to be statistically significant.

\section{Results and discussion}

The demand for products that improve the look and feel of hair has created a massive and high rentable industry based on the development of several strategies and application products for its care. Beauty care technology has advanced the cleaning, protection and restoration of desirable and specific hair properties by altering the hair fibre surface.

Although products and processes such as combing, chemical dyeing and permanent wave treatment are used to enhance appearance and hair styling, they also contribute greatly to 
chemical and mechanical damage to the fibres, which leads to degradation of structural and mechanical properties. As a result, the fibres become weak and more susceptible to breakage with time, which is incompatible with healthy hair [14]. There is a high focus in the development of new products, as novel applications or as part of the composition of shampoos and conditioners. The strategy here presented takes advantage of the potential ability of $\gamma \mathrm{D}$-crystallin to form a coat surrounding the hair fibres in a way that it will act as a 'protective shell' from damage and will improve the fibre mechanical performance. To fully exploit the $\gamma \mathrm{D}$-crystallin protein as a new hair care product, overbleached damaged hair was used in the study.

It is known that, during cataract development, insoluble aggregates of crystallins accumulate in the lens as amyloid fibrils and lead to light scattering and loss of lens clarity [15]. Protein precipitation and aggregation might occur by changes in the properties of crystallins driven by point mutations or age-related post-translational modifications [16]. Thus, two crystallins were used in the study. The wild type displays the same sequence as the human eye $\gamma \mathrm{D}$-crystallin, whereas the mutant results from site-directed mutagenesis of the wt form by substitution of three arginine residues $(R)$ at positions 14,36 and 79 by cysteine residues $(C)$.

Resembling already described mutant crystallins and other amyloid-forming proteins [17], three exposed arginines pointing towards three 'cardinal' positions were chosen as targets for direct mutagenesis. Cysteines are known to form covalent inner polypeptidic crosslinks giving stability to globular proteins. The presence of cysteines might induce a interunit crosslink in a network of mutant crystallins. This would also create possible points of anchorage to hair keratins that are naturally rich in cysteine residues. Thus, the mutant crystallin, with three additional cysteines (ARG15CYS, ARG37CYS and ARG80CYS) on its sequence, was used in order to fully exploit these possibilities.

In Fig. 1 is depicted the structure of the wt crystallin where the position of the three mutated arginines are highlighted in colour.

\section{Crystalline binding to overbleached hair}

When developing a new formulation for hair care, firstly the protein's ability to bind the hair fibre must be studied. This is crucial and ultimately will determine the formulation success. After the

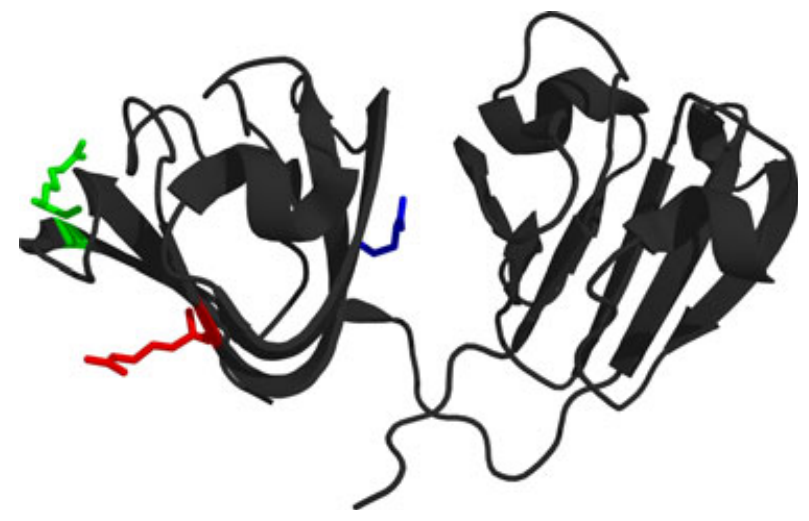

Figure 1 Schematic ribbon diagram depicting the overall structure of human $\gamma$ D-crystallin (Protein Data Bank ID: 1HKO); the three arginine residues that were mutated are showed using the stick model. hair treatments, roughly bound crystallins were washed off, and the remaining tightly bound proteins (at the hair surface and/or cortex) were visualized. Figure 2 shows the high-magnification SEM images of virgin, overbleached and treated Asian hair.

Although the SEM images do not supply any information about the amount of protein attached to the fibres, they provide a first clue about the ability of the proteins to bind hair. Comparing the micrographs of virgin hair (A and $\mathrm{B}$ ) with the micrographs of the hair treated with wt crystallin (E and F) and mut crystallin (G and $\mathrm{H})$, a thin film seems to form on the top of the hair fibres.

There are differences in the deposition pattern between the wt and mut crystallins. Although wt crystallin tends to deposit uniformly on the hair fibre, flattening the cuticle scales against each other, the deposition of mut crystallin resembles the deposition pattern of conditioners [14]. It is also possible to distinguish small protein aggregates formed close to the cuticle edges, most likely because of some degree of precipitation promoted by inherent protein structure instability and self-aggregation capacity of the mutant form.

Also the SEM images (C and D) demonstrate that bleaching results in hair cuticle damage, with the appearance of cracks and cuticle lifting.

The observation of SEM micrographs confirmed the ability of both crystallins to bind hair fibres. To fully exploit the degree of attachment and to evaluate whether the proteins deposit superficially or penetrate into the inner layers of the hair, the crystallins were labelled with FITC. In order to understand whether the Greek key motif is somehow essential for the ability of crystallins to bind, FITC-labelled globular protein BSA was used as a control, as it does not display the motif on its structure.

Figure 3 shows images of transversal cut hair fibres for unaltered human Asian hair (A), overbleached hair treated with BSA (B), overbleached hair treated with wt crystallin (C) and overbleached hair treated with mut crystallin (D). Although there are no significant differences in the intensity of the layer around the hair cuticle in overbleached hair treated with the wt crystallin and the mut crystallin, the layer on the wild-type form is thicker and more defined compared with the one formed by the mutant form. A strong increment in fluorescence is evident in both treatments when compared with virgin hair. The fluorescence images confirmed the deposition of labelled crystallins on hair. Moreover, it is evident that the two proteins are able to penetrate into the inner layers of the fibres.

Based on the higher number of cysteine residues of BSA (35) when compared with wt (6) and mut (9) crystallins, it was expected BSA would bind to the hair fibres more strongly than the two crystallins; however, the fluorescence images indicate the opposite.

The isoelectric point of human hair has been reported to be approximately 3.7 [18], indicating that hair possesses a net negative charge under most hair treatment conditions. Although none of the proteins present a net positive charge at $\mathrm{pH}$ 8.0, ideal in hair adsorption mechanisms guided by electrostatic interactions, BSA with a pI of 5.99 is the system with a higher deprotonation state and thus with a higher net negative charge resulting in repulsive forces between the protein and the hair fibre. Although both wt crystallin $(\mathrm{pI}=7.19)$ and the mut crystallin $(\mathrm{pI}=6.44)$ present a net negative charge at $\mathrm{pH}$ 8.0, they are not fully deprotonated and thus can adsorb to the hair fibre through electrostatic interactions. Other peptide-based treatments developed by our group revealed the ability to bind to and even penetrate hair fibres, despite the peptide's net negative charge $[19,20]$. 

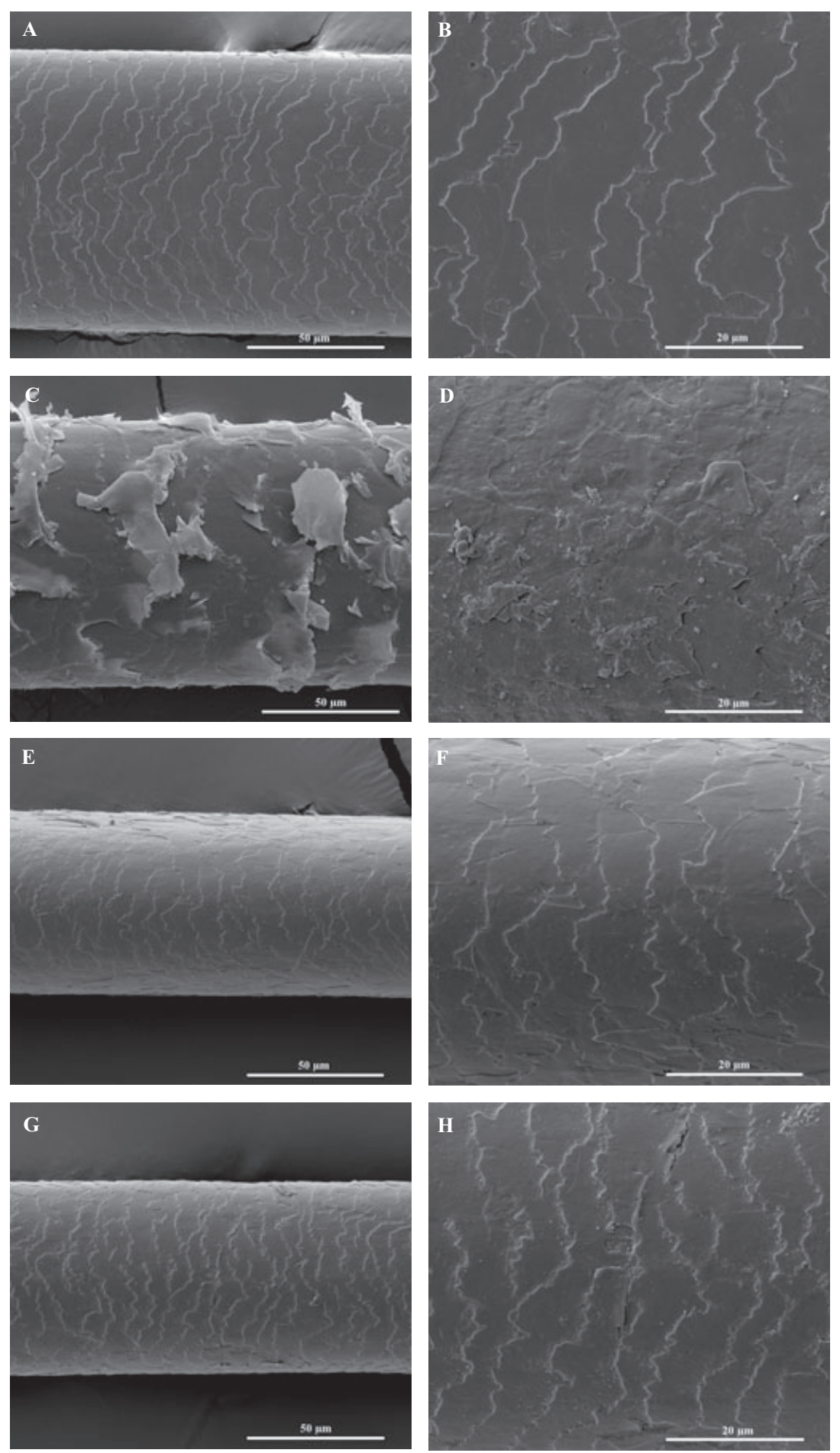

Figure 2 SEM micrographs of normal Asian virgin hair (A and B), over-bleached hair (C and D), overbleached hair treated with wild type crystallin (E and F) and over-bleached hair treated with mutant crystallin (G and $\mathrm{H})$.

Nevertheless, the proteins' isoelectric points as well as their molecular weights $(\mathrm{Mw})$ (molecule adsorption on damaged hair increases with decreasing Mw [21]) explain to some extent the differences in attachment to hair between crystallins and BSA. Other hypothesis is the innate ability of the Greek key motif to form stable multimolecular assemblies based on hydrophobic interactions [22]. Peptide 

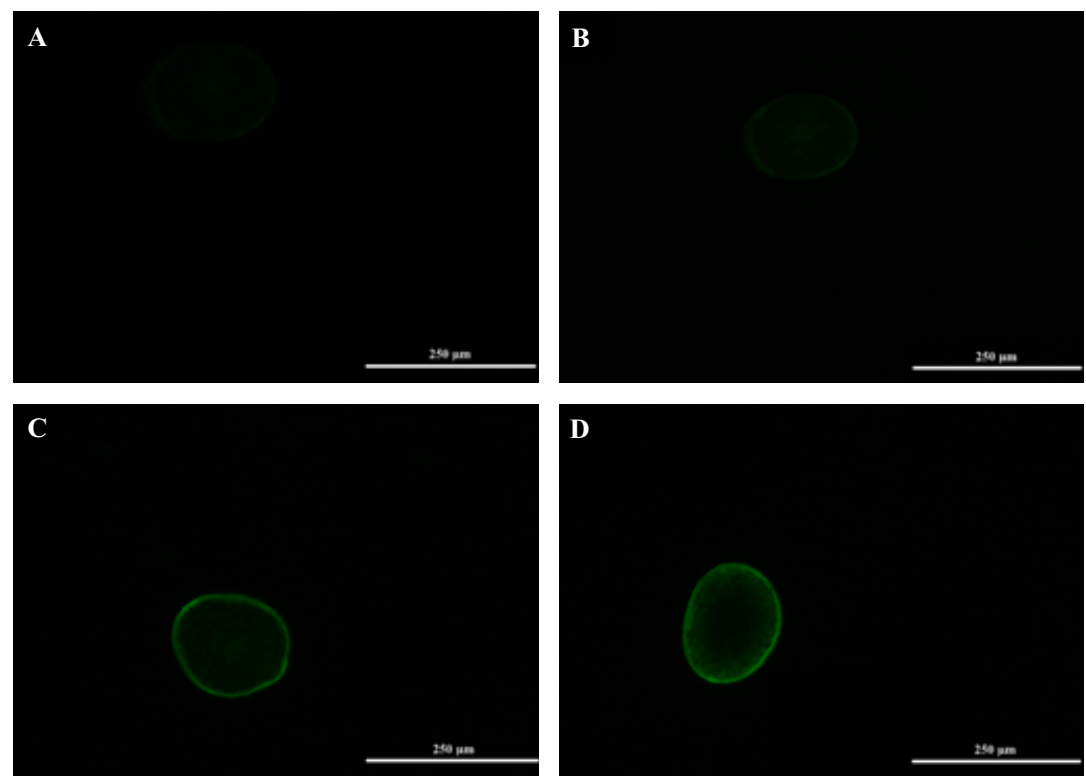

Figure 3 Fluorescence images of human hair cross sections from unaltered Asian virgin hair (A), overbleached hair treated with bovine serum albumin labelled with fluorescein 5(6)-isothiocyanate (FITC) (B), over-bleached hair treated with wild type crystallin labelled with FITC (C) and over-bleached hair treated with mutant crystallin labelled with FITC (D).

hydrophobicity is a critical parameter for cosmetic efficacy, and this peculiarity depends on its amino acid composition. The $\gamma \mathrm{D}$-crystallin protein presents a hydrophobic interface [21], which is most likely involved in the ligation of crystallins to the hair fibres.

To confirm crystallin penetration into the chemically damaged hair, samples of treated hair fibres were imaged using a laser scanning confocal microscope. 3D reconstructions are illustrated in Fig. 4. Both crystallins besides forming a film on the top of the hair fibre appear inside the fibre cortex. The impressive degree of penetration is evident as the protein diffuses into the entire cortex. Hair cuticle damage, with the appearance of cracks, holes and cuticle lifting as result of bleaching, could explain the high degree of penetration observed. These results suggest that the process of hair damaging is also a determinant of crystallins attachment and consequent diffusion.

\section{Recovery of the mechanical properties of overbleached hair}

Due to its intricate and unique structure, hair has remarkable mechanical properties, and the measurement of these is one of the simplest means of assessing the integrity and attributes of the fibre. Indeed, the slightest modification in the chemical composi- tion or structure of hair may greatly alter its mechanical properties [23].

After proving the affinity of wt and mut crystallins towards overbleached hair, we wanted to check their ability to recover or even improve the mechanical properties of damaged hair. Young's modulus and tensile strength are important parameters to determine hair's resistance. In Fig. 5 are presented the Young's modulus (A) and tensile strength (B) for overbleached hair, virgin hair and overbleached hair treated with both crystallins, BSA and with the protein buffer.

The repeated chemical bleaching treatments induced $22 \%$ of resistance loss when compared with the virgin, unaltered hair, measured in terms of Young's modulus, whereas there was a reduction in the hair fibres' maximum strength in order of about $15 \%$. Application of wt and mut crystallins resulted in the recovery of hair's mechanical properties in a magnitude of $50 \%$ in terms of Young's modulus and tensile strength. Indeed, the treatment of overbleached hair with protein buffer solution did not show any significant recovery of the mechanical properties, thus supporting the role of crystallins. Moreover, a statistically significant improvement in these features was noticed when both treatments are compared with virgin hair, except for the tensile strength in the hair fibres treated with $0.4 \mathrm{mg} \mathrm{mL}^{-1}$ of wt crystallin.

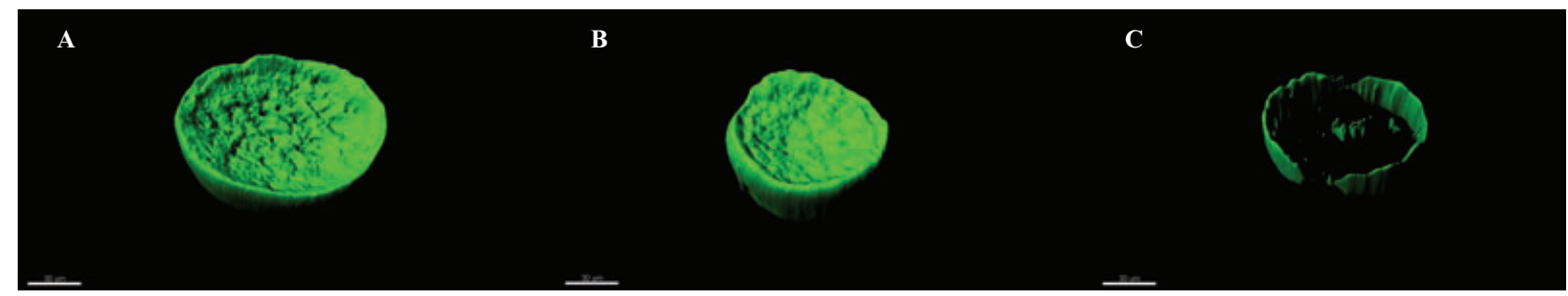

Figure 4 3D reconstruction from 'IMARIS' software of confocal microscopy of human hair cross sections. Over-bleached hair treated with mutant crystallin labelled with fluorescein 5(6)-isothiocyanate (FITC) (A), over-bleached hair treated with wild type crystallin labelled with FITC (B) and unaltered Asian virgin hair (C). 

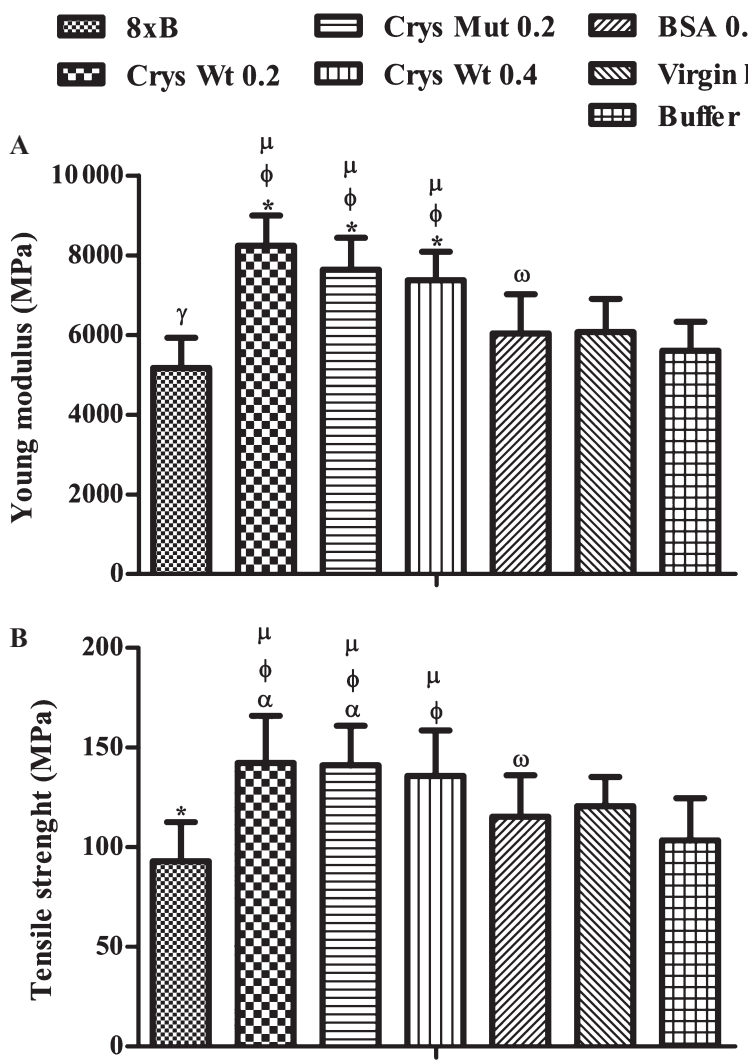

Figure 5 Mechanical resistance parameters: (A) Young's modulus and (B) tensile strength of virgin hair, over-bleached hair $(8 \mathrm{xB})$, over-bleached hair treated with $0.2 \mathrm{mg} \mathrm{mL}^{-1}$ of wild type crystallin (Crys wt 0.2 ), overbleached hair treated with $0.2 \mathrm{mg} \mathrm{mL}^{-1}$ of mutant crystallin (Crys mut 0.2 ), over-bleached hair treated with $0.4 \mathrm{mg} \mathrm{ml}^{-1}$ of wild type crystallin (Crys wt 0.4), over-bleached hair treated with $0.2 \mathrm{mg} \mathrm{ml}^{-1}$ of BSA (BSA 0.2 ) and over-bleached hair treated with the protein's buffer. Values are mean $\pm \mathrm{SD}$ of three independent experiments. $\omega P \leq 0.05$ when compared with $8 \mathrm{xB}$ hair, $\phi P \leq 0.001$ when compared with $8 \mathrm{xB}$ hair, $\alpha P \leq 0.05$ when compared with virgin hair, $\gamma P \leq 0.01$ when compared with virgin hair and $* P \leq 0.001$ when compared with virgin hair, $\mu P \leq 0.001$ when compared with $8 \mathrm{xB}$ hair treated with the protein's buffer.

The penetration of the proteins into the hair cortex (Fig. 4) and consequent stabilization of keratins' $\alpha$-helix, giving this structure a higher resistance to unfold during stretching, may explain the improvement in the mechanical properties. Nevertheless, this process is independent for higher protein concentrations since an increase in concentration, from 0.2 to $0.4 \mathrm{mg} \mathrm{mL}^{-1}$, did not result in an increase in hair's stiffness, indicating that protein penetration and peptide penetration into the hair cortex are prone to saturation.

Regarding BSA, although it did not penetrate into the hair cortex as crystallins, both Young's modulus and tensile strength results suggest its ability to recover hair resistance to values of the same magnitude as for virgin hair.

\section{Crystallins' cytotoxic effect evaluation}

When developing a new product that will contact with skin is of the outmost importance to assess its cytotoxicity. It is assumed that

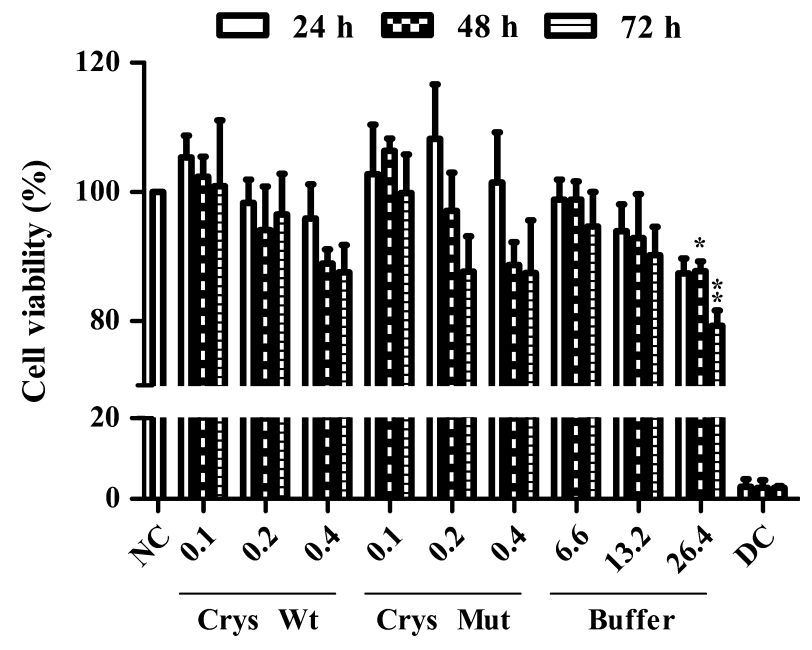

Figure 6 BJ-5ta cell viability measured by MTT assay at 24, 48 and $72 \mathrm{~h}$ of culture with three concentrations in $\mathrm{mg} \mathrm{ml}^{-1}$ of both crystallins and three concentrations in $\%(\mathrm{v} / \mathrm{v})$ of protein's buffer. Cell viability $(\%)$ is presented for each condition and each time point. The data represent mean \pm SD of three independent experiments, each with triplicates. Death control (DC) refers to the control of minimum cell survival. The results were compared with the control (NC): $* P \leq 0.05,{ }^{*} P \leq 0.01$.

almost every substance that is placed on human skin has the potential to produce physiological changes [24]. Thus, as the crystallins are to be applied on human hair and would therefore come into contact with the scalp, and even be adsorbed through it, the biocompatibility was evaluated using human skin fibroblasts in vitro (Fig. 6).

Some variations in cell viability are observed along time, although none with statistical significance can be pointed out with the exception of cells incubated with $26.4 \%$ (v/v) of buffer for 48 and $72 \mathrm{~h}$.

Neither wt nor mut crystallins display any significant toxicity throughout the experiment.

An increase in protein concentration seems to result in decreased cell viability; however, the similarity of results between crystallins and buffer clearly indicates that the reduction in viability relates simply to the dilution factor introduced by the buffer in which proteins are resuspended.

There is an inverse relation between the buffer concentration and cell viability since an increase in buffer concentration, from 6.6 to $26.4 \%(\mathrm{v} / \mathrm{v})$, results in decreased viability.

\section{Evaluation of the inflammatory effect of crystallins}

After measuring toxicity, the potential of both proteins for inducing an immune response was also evaluated using the BJ-5ta cell line. Fibroblasts have traditionally been associated with a structural component mainly involved in the synthesis of extracellular matrix. However, fibroblasts play an active role in modulating immune cell behaviour by conditioning the local cellular and molecular milieu. Fibroblast activation leads to the production of cytokines, chemokines and prostanoids such as prostaglandin E2 [25]. IL-6 is one of the pro-inflammatory factors produced by dermal fibroblasts in response to stimuli. Measuring this cytokine after exposing dermal 
Table II Quantification by ELISA of IL-6 produced by BJ-5ta cell line after exposition to wild-type and mutant crystallins. No treatment corresponds to cells incubated with culture media (negative control) and $\mathrm{IL}-1 \beta$ to cells exposed to an inflammatory cytokine (positive control)

\section{IL-6 pg mL $\mathrm{mL}^{-1}$}

$24 \mathrm{~h}$

No treatment

IL-1 $\beta$

Crys wt 0.2

Crys mut 0.2
$48 \mathrm{~h}$

$83.12 \pm 4.26$
$\gg 1000$
$90.95 \pm 39.36$
$1206.54 \pm 280.01$

$33.75 \pm 4.83$

$\gg 1000$

$91.89 \pm 5.05$
$77.01 \pm 25.97$

fibroblasts in vitro to crystalline proteins allows predicting the immunogenic capability of these proteins if somehow they could be absorb through the scalp. According to the results shown in Table II, when compared with the positive control for an inflammation state of fibroblasts (in the presence of IL- $1 \beta$ ), only mut crystallin is able to trigger the production of significant amounts of IL-6 after $24 \mathrm{~h}$ of exposure. After $48 \mathrm{~h}$, the IL- 6 levels decreased for fibroblasts exposed to the mut form, whereas for the wt, levels are maintained. In both cases, the levels are slightly above the levels of the negative control. Mutant crystallin proteins are much less stable than the wt, as seen by the visible protein aggregation in culture media (not shown). Similar to what happens to amyloid proteins whose intermediate folding species are more cytotoxic than the final protein aggregates [26], the mut crystallin may transiently induce an inflammatory response during the process of active aggregation where the reactive intermediate folding states occur at higher levels. Wild-type crystallin does not significantly trigger the pro-inflammatory cytokine IL- 6 release by fibroblasts.

\section{Conclusions}

The present study intended to evaluate the potential of proteinbased formulations as restorative hair care products. The wild- type and the mutant crystallins were able to restore and improve the mechanical properties of overbleached hair to values higher than the ones displayed by virgin, unaltered hair. Both proteins deposit and strongly bind to the damaged hair. Moreover, the two crystallins were capable of penetrating into the fibre cortex, a condition that seems essential for the improvement of the mechanical properties when compared with the virgin hair reference values. This condition was supported by the treatment with BSA, since this protein was not able to penetrate into the cortex, and thus, its action was limited to the recovery of the mechanical properties. Most likely the proteins size, the net charge and structure are key factors for the inability to bind and/or penetrate into the hair fibres.

The cytotoxic studies demonstrate that the two crystallins, at the tested concentrations, do not affect cells viability. The in vitro observed cytotoxicity is not an issue for the application in hair since the effect of medium dilution is not a determinant in a cosmetic application.

Although the two tested crystallins present similar results regarding the recovery/improvement of the mechanical properties and cytotoxicity, the wild-type crystallin is the best suited for a cosmetic application since the mutant crystallin displayed an inflammatory response on fibroblasts. The process of active aggregation of the mutant crystallin is most likely responsible for the inflammatory process. Also this aggregation process possibly influenced the protein imaging properties as the wild-type crystallin tends to deposit uniformly on the hair fibre, flattening the cuticle scales against each other, whereas the mutant crystallin forms small aggregates on the cuticles edges.

The $\gamma \mathrm{D}$-crystallin proved to be an excellent candidate for a new restorative hair care product, opening new perspectives for other proteins belonging to the superfamily characterized structurally by the Greek key motif to be used in hair cosmetics.

\section{Acknowledgements}

This work is supported by FEDER through POFC-COMPETE and by national funds from FCT through the project PEst-C/BIA/UI4050/ 2011.

\section{References}

1. Skopp, G., Pijtschb, L. and Moeller, M.R. On cosmetically treated hair - aspects and pitfalls of interpretation. Forensic Sci. Int. 84, 43-52 (1997).

2. Bolduc, C. and Shapiro, J. Hair care products: waving, straightening, conditioning, and coloring. Clin. Dermatol. 19, 431-436 (2001).

3. Brown, K.C. Hair coloring. In: Hair and Hair Care (Johnson, D.H., ed.), pp. 191-215. Marcel Dekker, New York (1997).

4. Turowski, A. and Adlmann-Grill, B.C. Substantivity to hair and skin of 125 - labelled collagen hydrolysates under application simulating conditions. Int. J. Cosmet. Sci. 7, 7174 (1985).

5. Secchi, G. Role of protein in cosmetics. Clin. Dermatol. 26, 321-325 (2008).
6. Bloemendal, H., de Jong, W., Jaenicke, R., Lubsen, N.H., Slingsby, C. and Tardieu, A. Ageing and vision: structure, stability and function of lens crystallins. Prog. Biophys. Mol. Biol. 86, 407-485 (2004).

7. Zhao, H., Brown, P.H., Magonel, T. and Schuck, P. The molecular refractive function of lens $\gamma$-Crystallins. J. Mol. Biol. 411, 680699 (2011).

8. Lubsen, N.H., Aarts, H.J. and Schoenmakers, J.G. The evolution of lenticular proteins: the beta and gamma-crystallin super gene family. Prog. Biophys. Mol. Biol. 51, 47-76 (1988).

9. Jaenicke, R. Stability and folding of domain proteins. Prog. Biophys. Mol. Biol. 71, 155241 (1999).

10. Richardson, J.S. $\beta$-Sheet topology and the relatedness of proteins. Nature 268, 495500 (1977).
11. Bagby, S., Go, S., Inouye, S., Ikura, M. and Chakrabartty, A. Equilibrium folding intermediates of a Greek key $\beta$-barrel protein. J. Mol. Biol. 276, 669-681 (1998).

12. Wistow, G., Summers, L. and Blundell, T. Myxococcus xanthus spore coat protein S may have a similar structure to vertebrate lens beta gammacrystallins. Nature $\mathbf{3 1 5}$, 771-773 (1985).

13. Liu, Y. and Schubert, D. Cytotoxic amyloid peptides inhibit cellular 3-(4,5-dimethylthiazol -2-yl)-2,5-diphenyltetrazolium bromide (MTT) reduction by enhancing MTT formazan exocytosis. J. Neurochem. 69, 2285-2293 (1997).

14. Bhushan, B. Nanoscale characterization of human hair and hair conditioners. Prog. Mater Sci. 53, 585-710 (2008).

15. Hoenders, H.J. and Bloemendal, H. Lens proteins and aging. J Gerontol. 38, 278-286 (1983). 
16. Papanikolopoulou, K., Mills-Henry, I., Thol, S.L. et al. Formation of amyloid fibrils in vitro by human $\gamma$ D-crystallin and its isolated domains. Mol. Vis. 14, 81-89 (2008).

17. Meehan, S., Berry, Y., Luisi, B., Dobson, C.M., Carver, J.A. and MacPhee, C.E. Amyloid fibril formation by lens crystallin proteins and its implications for cataract formation. J. Biol. Chem. 279, 3413-3419 (2004).

18. Regismon, S.T.A., Heng, Y.M., Goddard, E.D. and Winnik, F.M. Fluorescence microscopy observation of the adsorption onto hair of a fluorescently labelled cationic cellulose ether. Langmuir 15, 3007-3010 (1999).

19. Fernandes, M. and Cavaco-Paulo, A. Protein disulphide isomerase-mediated grafting of cysteine-containing peptides onto over- bleached hair. Biocatal. Biotransform. 30, 10-19 (2012).

20. Fernandes, M.M., Lima, C.F., Loureiro, A., Gomes, A.C. and Cavaco-Paulo, A. Keratinbased peptide: biological evaluation and strengthening properties on relaxed hair. Int. J. Cosmet. Sci. 34, 338-346 (2012).

21. Faucher, J.A. and Goddard, E.D. Sorption of a cationic polymer by stratum corneum. J. Soc. Cosmet. Chem. 27, 543-553 (1976).

22. Bagby, S., Harvey, T.S., Eagle, S.G., Inouye, S. and Ikura, M. Structural similarity of a developmentally regulated bacterial spore coat protein to beta gamma-crystallins of the vertebrate eye lens. Proc. Natl Acad. Sci. USA 91, 4308-4312 (1994).

23. Franbourg, A. and Leroy, F. Hair structure, function, and physicochemical properties.
In: The Science of Hair Care (Bouillon, C., Wilkinson, J. ed.), pp. 1-74. CRC Press Taylor \& Francis Group, New York (2005).

24. Nohynek, G.J., Antignac, E., Re, T. and Toutain, H. Safety assessment of personal care products/cosmetics and their ingredients. Toxicol. Appl. Pharmacol. 243, 239-259 (2010).

25. Flavell, S.J., Hou, T.Z., Lax, S., Filer, A.D., Salmon, M. and Buckley, C.D. Fibroblasts as novel therapeutic targets in chronic inflammation. Br. J. Pharmacol. 153, 241-246 (2008).

26. Andersson, K., Olofsson, A., Nielsen, E.H., Svehag, S.E. and Lundgrena, E. Only amyloidogenic intermediates of transthyretin induce apoptosis. Biochem. Biophys. Res. Commun. 294, 309-314 (2002). 